\title{
ANALISIS DAYA DUKUNG FONDASI DALAM DENGAN METODE INNER BORING DI JAKARTA
}

\author{
Shella Christiani' ${ }^{1}$, Aksan Kawanda ${ }^{2}$ \\ ${ }^{1}$ Program Studi Sarjana Teknik Sipil, Universitas Tarumanagara, Jl. Letjen S. Parman No.1 Jakarta \\ Email: Shellachristianii@gmail.com \\ ${ }^{2}$ Program Studi Sarjana Teknik Sipil, Universitas Tarumanagara, Jl. Letjen S. Parman No.1 Jakarta \\ Email: Akawanda@geotech-indonesia.com
}

\begin{abstract}
ABSTRAK
Dewasa ini tingkat pembangunan semakin meningkat mengikuti bertambahnya populasi penduduk. Pada umumnya lahan yang tersedia untuk pembangunan di kota-kota besar relatif kecil serta berhimpitan dengan bangunan-bangunan di sekitarnya sehingga di perlukannya alternatif teknik instalasi fondasi yang minim getaran. Inner boring merupakan sebuah teknologi pemasangan tiang fondasi pracetak (spun pile) yang mengkombinasikan metode drilling dan jacking dengan cara melubangi tanah dengan bor sambil memasukan tiang fondasi dengan cara di tekan. Tugas akhir ini membahas analisa perbandingan daya dukung fondasi dalam dengan metode instalasi Inner boring ,Pancang, dan Bored pile serta membandingkan dengan data uji beban-VWSG. Perhitungan daya dukung fondasi Inner boring menggunakan metode Nakabori Kakutei System (NAKS). Perhitungan daya dukung Pancang dihitung dengan membandingkan metode Meyerhof, Brown, dan Briaud .et.al. Sedangkan fondasi Bored pile dihitung dengan membandingkan metode Meyerhof, Reese and Wright, dan Luciano de Court. Analisa perhitungan dilakukan pada tiang fondasi pracetak berongga berdiameter $1200 \mathrm{~mm}$ dengan kedalaman $21 \mathrm{~m}$
\end{abstract}

Kata kunci: Inner-boring, Bored-pile, VWSG, Daya dukung

\section{PENDAHULUAN}

Fondasi merupakan struktur bangunan yang menyalurkan beban dari struktur atas ke lapisan tanah, dimana fondasi juga menentukan kestabilan suatu struktur bangunan. Secara umum fondasi dapat didefinisikan sebagai suatu bagian dari konstruksi bangunan yang bertugas meletakkan bangunan dan meneruskan beban bangunan atas ke tanah dasar yang cukup kuat mendukungnya serta memberikan kestabilan pada struktur bangunan dalam memikul beban baik horisontal maupun vertikal. Fungsi ini dapat berjalan secara optimal bila kestablian terhadap daya dukung tanah terpenuhi.

Dewasa ini tingkat pembangunan semakin meningkat mengikuti bertambahnya populasi penduduk. Pada umumnya lahan yang tersedia untuk pembangunan di kota-kota besar relatif kecil serta berhimpitan dengan bangunanbangunan di sekitarnya sehingga di perlukannya alternatif teknik instalasi fondasi yang minim getaran. Secara umum permasalahan fondasi dalam lebih rumit dari pondasi dangkal. Terdapat beberapa jenis sistem pemancangan fondasi dalam pelaksanaannya, yaitu Drop hammer, Jacked pile, Bored pile, dan yang terbaru adalah Inner Boring.

Teknologi Inner Boring menjawab sejumlah tuntutan pembangunan di wiliyah perkotaan antara lain di bawah ambang batas kebisingan, tidak boleh bergetar karena dapat membuat retak bangunan sekitar dan tidak mengotori lingkungan kerja. Inner Boring merupakan metode instalasi tiang pancang yang berkembang di Jepang dimana teknologi ini berasal dari penggabungan metode conventional pre-drilling dan Jacked-in Pile. Teknologi ini menawarkan sejumlah keunggulan seperti tidak bising, tidak begetar, tidak mengotori lingkungan, namun tidak melupakan kecepatan pelaksanaan. Sistem pemancangan dengan metode Inner Boring tidak menghasilkan getaran karena melubangi tanah dengan cara di bor sambil di masukkan tiang pancang dengan cara di tekan, dalam pengerjaannya teknologi ini lebih cepat dibandingkan teknologi konvensional, serta tidak mengotori lingkungan kerja proyek karena tanah yang dibor langsung ditampung pada bucket untuk langsung di pindahkan. Pembahasan dalam penelitian ini adalah analisis daya dukung fondasi tiang yang di pasang dengan metode inner boring. Analisis dilakukan dengan Instrumented Static Load Test.

Perhitungan daya dukung fondasi dalam dinyatakan dalam bentuk:

$$
Q_{u}=Q_{s}+Q_{p}
$$

Dengan $Q_{u}=$ Daya dukung ultimate tiang, $Q_{s}=$ Daya dukung selimut tiang, dan $Q_{p}=$ Daya dukung ujung tiang 


\section{Daya Dukung Tiang Pancang}

Perhitungan kapasitas daya dukung fondasi tiang pancang menggunakan metode Meyerhof, Brown, dan Briaud.et.al. Berikut merupakan persamaan yang digunakan mengutip dari

Metode Meyerhof (Hardiyatmo,2008)

Tanah non kohesif:

$$
\begin{aligned}
& Q_{p}=40 \cdot N_{s p t} \cdot A_{p} \\
& Q_{s}=2 \cdot N_{s p t} \cdot L_{i} \cdot P
\end{aligned}
$$

Tanah kohesif:

$$
\begin{array}{r}
Q_{p}=9 . C_{u .} A_{p} \\
Q_{s}=\alpha \cdot C_{u} . P . L_{i}
\end{array}
$$

dengan $Q_{p}=$ Daya dukung ujung tiang, $Q_{s}=$ Daya dukung selimut tiang, $N_{S P T}=$ Nilai $N_{S P T}$ pada elevasi dasar tiang, $A_{p}=$ Luas penampang dasar tiang, $L_{i}=$ Panjang Tiang, $P=$ Perimeter Tiang, $C_{u}=$ Kuat geser, dan $\alpha=$ Faktor adhesi

Metode Brown (Paulus, 2013)

Perhitungan daya dukung selimut tiang:

$$
Q_{s}=A_{s} . f_{s}
$$

Perhitungan daya dukung ujung tiang:

$$
Q_{p}=A_{p .} q_{p}
$$

dengan $Q_{p}=$ Daya dukung ujung tiang, $Q_{s}=$ Daya dukung selimut tiang, $A_{p}=$ Luas penampangan ujung tiang, $A_{s}=$ Luas selimut tiang, $f_{s}=$ Tahanan selimut tiang, dan $q_{p}=$ Tahanan ujung tiang

Metode Briaud.et.al (Paulus, 2013)

Perhitungan daya dukung ujung tiang:

$$
\begin{array}{r}
Q_{p}=A_{p} f_{b} \\
f_{b}=19,7 \cdot \sigma_{r} \cdot\left(N_{60}\right)^{0.36}
\end{array}
$$

Perhitungan daya dukung selimut tiang:

$$
\begin{array}{r}
Q_{p}=A_{p} f_{s} \\
f_{s}=0,224 . \sigma_{r} \cdot\left(N_{60}\right)^{0.29}
\end{array}
$$

Dengan $Q_{p}=$ Daya dukung ujung tiang, $Q_{s}=$ Daya dukung selimut tiang, $f_{s}=$ Tahanan selimut tiang, $f_{b}=$ Tahanan ujung tiang, $\sigma_{r}=$ Tegangan referensi, dan $N_{60}=$ Nilai Nspt koreksi

\section{Daya Dukung Tiang Bor}

\section{Metode Meyerhof (Hardiyatmo,2008)}

Tanah non kohesif:

$$
\begin{aligned}
& Q_{p}=40 . N_{s p t} \cdot A_{p} \\
& Q_{s}=2 . N_{s p t} \cdot L_{i} \cdot P
\end{aligned}
$$

Tanah kohesif: 


$$
\begin{array}{r}
Q_{p}=9 \cdot C_{u} \cdot A_{p} \\
Q_{s}=\alpha \cdot C_{u} \cdot P \cdot L_{i}
\end{array}
$$

dengan $Q_{p}=$ Daya dukung ujung tiang, $Q_{s}=$ Daya dukung selimut tiang, $N_{S P T}=$ Nilai $N_{S P T}$ pada elevasi dasar tiang, $A_{p}=$ Luas penampang dasar tiang, $L_{i}=$ Panjang Tiang, $P=$ Perimeter Tiang, $C_{u}=$ Kuat geser, dan $\alpha=$ Faktor adhesi

Metode Reese and Wright (Reese.C, 2006)

Daya dukung ujung tiang:

$$
Q_{p}=q_{p} \cdot A_{p}
$$

Daya dukung selimut tiang

$$
Q_{s}=f_{s} . L . P
$$

dengan $Q_{p}=$ Daya dukung ujung tiang, $Q_{s}=$ Daya dukung selimut tiang, $A_{p}=$ Luas penampangan ujung tiang, $A_{s}=$ Luas selimut tiang, $f_{s}=$ Tahanan selimut tiang, dan $q_{p}=$ Tahanan ujung tiang, $L_{i}=$ Panjang Tiang

Metode Luciano de Court (Paulus, 2013)

$$
\begin{array}{r}
Q_{p}=A_{p} N_{p} K \\
Q_{s}=A_{s}\left(\frac{N_{s}}{3}+1\right)
\end{array}
$$

dengan $Q_{p}=$ Daya dukung ujung tiang, $Q_{s}=$ Daya dukung selimut tiang, $A_{p}=$ Luas penampangan ujung tiang, $A_{s}=$ Luas selimut tiang, $N_{p}=$ Rata-rata dari harga SPT yang telah dikoreksi mulai 4D di bawah ujung tiang sampai 4D di atas tiang, $N_{s}=$ Harga SPT rata-rata pada lapisan tanah yang telah dikoreksi sepanjang tiang yang ditinjau, $K=$ Koefisien yang tergantung dari jenis tanah

\section{Daya Dukung Inner boring}

\section{Metode Nakabori}

Perhitungan kapasitas daya dukung fondasi Inner boring menggunakan metode Nakabori (Aksan Kawanda,2015) dengan persamaan sebagai berikut:

$$
\begin{gathered}
R_{u l t}=\alpha \cdot N \cdot A_{p}+\beta \cdot N_{s} \cdot L_{s} \cdot p+\gamma \cdot q_{u} \cdot L_{c} \cdot p \\
R_{\text {all }}=\frac{R_{u l t}}{S F}
\end{gathered}
$$

Kapasitas gesekan pada fondasi Inner Boring dibagi menjadi 2 bagian yaitu (1) natural zone dan (2) improvement zone dimana improvement zone sangat berguna untuk meningkatkan kapasitas gesekan tiang.

Zona 1

$$
\begin{gathered}
\beta_{1}=1.5 \\
\gamma_{1} \cdot q_{u}=15+0,125 \cdot q_{u}
\end{gathered}
$$

Zona 2

$$
\begin{gathered}
\beta_{1}=3.5 \\
\gamma_{2} \cdot q_{u}=20+0,4 \cdot q_{u}
\end{gathered}
$$

dengan $R_{u l t}=$ Daya dukung ultimate tiang, $R_{\text {all }}=$ Daya dukung ijin tiang, $N=$ Nilai SPT rata-rata ujung tiang, $A_{p}=$ Luas penampang tiang, $N_{s}=$ Nilai SPT rata-rata sisi samping tiang, $q_{u}=$ Undrained shear strength, $L_{s}=$ Panjang tiang pada lapisan pasir, $L_{c}=$ Panjang tiang pada lapisan lempung, $P=$ Keliling tiang, $\alpha=$ Koefisien ujung tiang, $\beta=$ Koefisien gesekan tiang pada lapisan pasir, $\gamma=$ Koefisien gesekan tiang pada lapisan lempung, dan $S F=$ Faktor keamanan 


\section{METODOLOGI PENELITIAN}

Langkah-langkah penelitian berupa diagram alir yang dilakukan dapat dilihat pada diagram berikut ini:

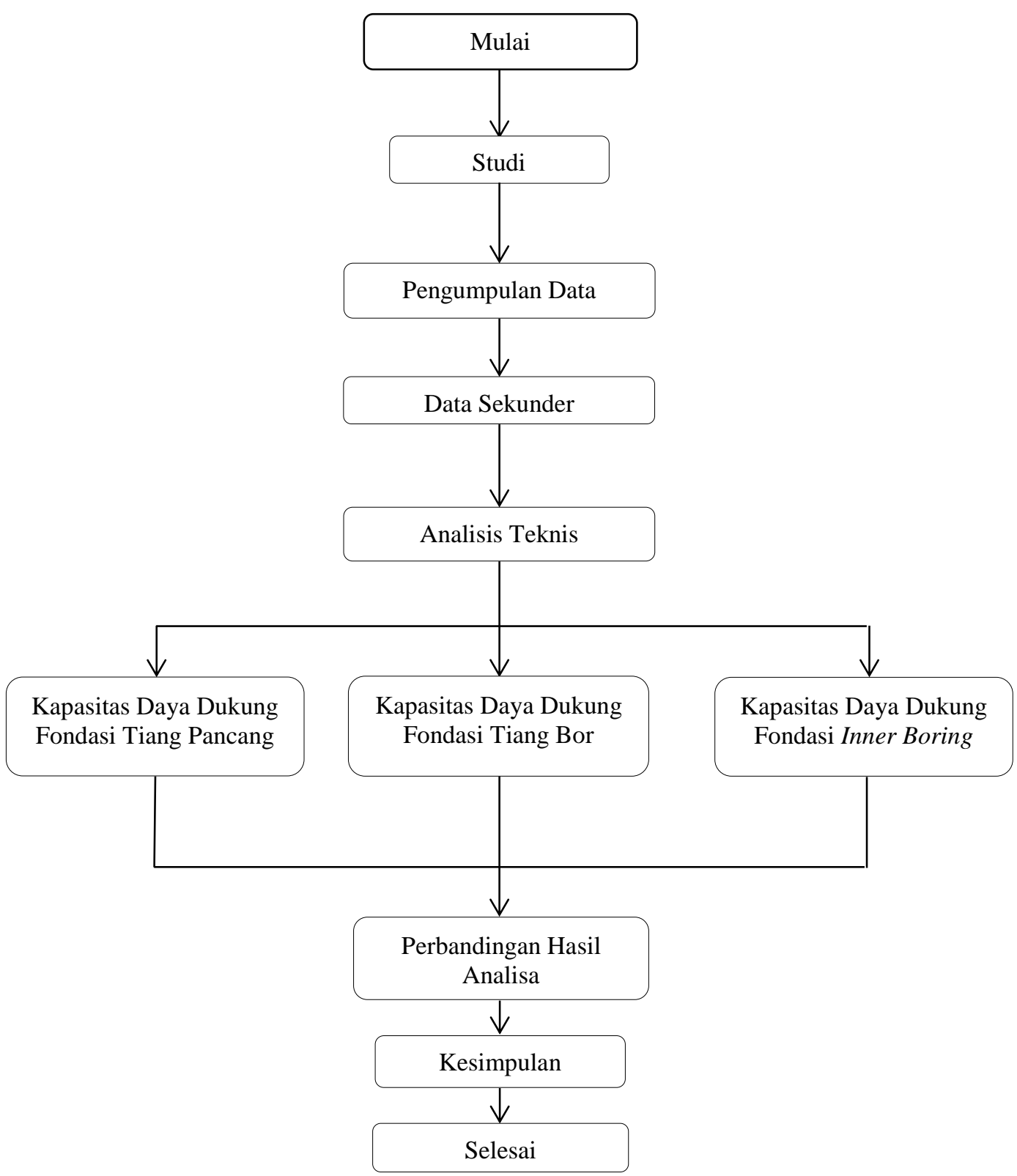

Gambar 1. Diagram Alir Penelitian

\section{HASIL DAN PEMBAHASAN}

Penyelidikan tanah yang dilakukan pada proyek di Jakarta menggunakan jenis mesin peralatan bor mesin. Pengeboran dilakukan pada 3 titik yaitu DB I, DBII, DB III hingga kedalaman 25 meter pada tiap titiknya

Tabel 1. Nilai $N_{S P T}$ Pada Titik DB-I, DB-II, DB-III

\begin{tabular}{cccc}
\hline & \multicolumn{3}{c}{ N-SPT } \\
\hline Depth & DB-I & DB-II & DB-III \\
\hline 0 & 0 & 0 & 0 \\
\hline 1 & 3 & 6 & 5
\end{tabular}




\begin{tabular}{|c|c|c|c|}
\hline & \multicolumn{3}{|c|}{ N-SPT } \\
\hline Depth & DB-I & DB-II & DB-III \\
\hline 2 & 3 & 10 & 7 \\
\hline 3 & 4 & 12 & 10 \\
\hline 4 & 6 & 5 & 12 \\
\hline 5 & 4 & 6 & 7 \\
\hline 6 & 3 & 7 & 5 \\
\hline 7 & 3 & 8 & 6 \\
\hline 8 & 4 & 7 & 9 \\
\hline 9 & 5 & 9 & 20 \\
\hline 10 & 5 & 12 & 25 \\
\hline 11 & 5 & 15 & 10 \\
\hline 12 & 10 & 15 & 12 \\
\hline 13 & 16 & 9 & 15 \\
\hline 14 & 14 & 10 & 16 \\
\hline 15 & 15 & 20 & 26 \\
\hline 16 & 21 & 28 & 37 \\
\hline 17 & 30 & 35 & 48 \\
\hline 18 & 43 & 49 & 55 \\
\hline 19 & 60 & 58 & 60 \\
\hline 20 & 55 & 58 & 60 \\
\hline 21 & 55 & 55 & 60 \\
\hline 22 & 60 & 53 & 60 \\
\hline 23 & 54 & 56 & 58 \\
\hline 24 & 46 & 60 & 57 \\
\hline 25 & 44 & 60 & 60 \\
\hline
\end{tabular}

Perhitungan daya dukung tiang fondasi pancang, bor, dan inner boring dilakukan pada tiang dengan diameter 1200 $\mathrm{mm}$, ketebalan $15 \mathrm{~cm}$, dan kedalaman $21 \mathrm{~m}$.

Perhitungan daya dukung tiang pancang menggunakan metode perhitungan Meyerhof, Brown, dan Briaud.et.al, Berikut merupakan perhitungan kapasitas daya dukung friksi, ujung, dan ultimit pada tiang pancang:

Tabel 2.Resume Daya Dukung Tiang Pancang Metode Meyerhof pada DB-I, DB-II, DB-III

\begin{tabular}{cccc}
\hline Titik Bor & Qs(Ton) & Qp(Ton) & Qu(Ton) \\
\hline DB-I & 402 & 1089 & 1491 \\
\hline DB-II & 496 & 1089 & 1584 \\
\hline DB-III & 504 & 1188 & 1691
\end{tabular}

Tabel 3.Resume Daya Dukung Tiang Pancang Metode Brown pada DB-I, DB-II, DB-III

\begin{tabular}{cccc}
\hline Titik Bor & Qs(Ton) & Qp(Ton) & Qu(Ton) \\
\hline DB-I & 443 & 407 & 850 \\
\hline DB-II & 488 & 407 & 894 \\
\hline DB-III & 527 & 442 & 970 \\
\hline
\end{tabular}


Tabel 4.Resume Daya Dukung Tiang Pancang Metode Briaud.et.al pada DB-I, DB-II, DB-III

\begin{tabular}{cccc}
\hline Titik Bor & Qs(Ton) & Qp(Ton) & Qu(Ton) \\
\hline DB-I & 348 & 394 & 742 \\
\hline DB-II & 383 & 394 & 777 \\
\hline DB-III & 401 & 406 & 807 \\
\hline
\end{tabular}

Perhitungan daya dukung tiang bor menggunakan metode perhitungan Meyerhof, Reese and Wright, dan Luciano de Court, Berikut merupakan perhitungan kapasitas daya dukung friksi, ujung, dan ultimit pada tiang bor:

Tabel 5.Resume Daya Dukung Tiang Bor Metode Meyerhof pada DB-I, DB-II, DB-III

\begin{tabular}{cccc}
\hline Titik Bor & Qs (Ton) & Qp(Ton) & Qu(Ton) \\
\hline DB-I & 387 & 1089 & 1475 \\
\hline DB-II & 445 & 1089 & 1534 \\
\hline DB-III & 486 & 1188 & 1673 \\
\hline
\end{tabular}

Tabel 6.Resume Daya Dukung Tiang Bor Metode Reese and Wright pada DB-I, DB-II, DB-III

\begin{tabular}{cccc}
\hline Titik Bor & Qs(Ton) & Qp(Ton) & Qu(Ton) \\
\hline DB-I & 461 & 195 & 656 \\
\hline DB-II & 539 & 195 & 734 \\
\hline DB-III & 586 & 212 & 799 \\
\hline
\end{tabular}

Tabel 7.Resume Daya Dukung Tiang Bor Metode Luciano de Court pada DB-I, DB-II, DB-III

\begin{tabular}{cccc}
\hline Titik Bor & Qs(Ton) & Qp(Ton) & Qu(Ton) \\
\hline DB-I & 483 & 563 & 1047 \\
\hline DB-II & 560 & 993 & 1553 \\
\hline DB-III & 639 & 640 & 1280 \\
\hline
\end{tabular}

Perhitungan daya dukung friksi, ujung, serta ulitimit tiang inner boring dengan metode perhitungan Nakabori

Tabel 8.Resume Daya Dukung Inner Boring Metode Nakabori pada DB-I, DB-II, DB-III

\begin{tabular}{cccc}
\hline Titik Bor & Qs(Ton) & Qp(Ton) & Qu(Ton) \\
\hline DB-I & 515 & 980 & 1495 \\
\hline DB-II & 613 & 980 & 1592 \\
\hline DB-III & 595 & 1069 & 1664 \\
\hline
\end{tabular}

Perhitungan data uji pembebanan statik dilakukan pada tiang dengan diameter $1200 \mathrm{~mm}$, ketebalan $15 \mathrm{~cm}$, dan kedalaman $20.5 \mathrm{~m}$

Tabel 9. Rekaman Data VWSG Elevasi $20.5 \mathrm{~m}$ 


\begin{tabular}{cccc}
\hline & & \multicolumn{2}{c}{20.5} \\
\hline Load(\%) & Load(ton) & $\mathrm{A}$ & $\mathrm{B}$ \\
\hline $0 \%$ & 0 & 2435 & 2435 \\
\hline $25 \%$ & 115 & 2422 & 2422 \\
\hline $50 \%$ & 230 & 2406 & 2406 \\
\hline $0 \%$ & 0 & 2432 & 2432 \\
\hline $75 \%$ & 345 & 2401 & 2401 \\
\hline $100 \%$ & 460 & 2366 & 2366 \\
\hline $0 \%$ & 0 & 2435 & 2435 \\
\hline $125 \%$ & 575 & 2333 & 2333 \\
\hline $150 \%$ & 690 & 2301 & 2301 \\
\hline $0 \%$ & 0 & 2422 & 2422 \\
\hline $175 \%$ & 805 & 2270 & 2270 \\
\hline $200 \%$ & 920 & 2205 & 2205 \\
\hline
\end{tabular}

Tabel 10. Perhitungan Load Transfer

\begin{tabular}{cccccccc}
\hline & \multicolumn{7}{c}{$\mathrm{P}(\mathrm{Ton})$} \\
\cline { 2 - 7 } & 1 & 10.5 & 12.5 & 14.5 & 16.5 & 18.5 & 20.5 \\
\hline $25 \%$ & 115 & 113.65 & 113.65 & 113.65 & 113.65 & 83.88 & 67.72 \\
\hline $50 \%$ & 230 & 228.83 & 228.83 & 226.50 & 226.50 & 189.14 & 75.32 \\
\hline $75 \%$ & 345 & 345.00 & 342.57 & 342.57 & 342.57 & 313.42 & 158.13 \\
\hline $100 \%$ & 460 & 457.60 & 455.21 & 455.21 & 455.21 & 419.27 & 242.36 \\
\hline $125 \%$ & 575 & 575.00 & 575.00 & 575.00 & 572.62 & 515.60 & 309.23 \\
\hline $150 \%$ & 690 & 687.69 & 687.69 & 687.69 & 687.69 & 611.54 & 356.73 \\
\hline $200 \%$ & 920 & 920.00 & 917.97 & 917.97 & 915.95 & 816.65 & 439.74 \\
\hline
\end{tabular}

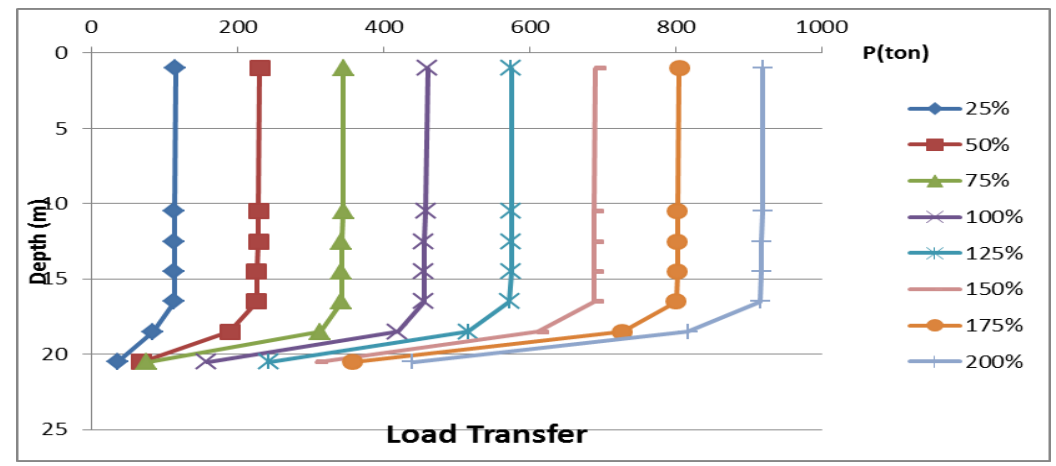

Gambar 1. Load Transfer

Tabel 11. Perhitungan Daya Dukung Friksi $\left(Q_{S}\right)$ 


\begin{tabular}{cccccccc}
\hline & \multicolumn{5}{c}{ Elevasi (m) } & \multirow{2}{*}{ Cumm } \\
\hline & $1-10.5$ & $10.5-12.5$ & $12.5-14.5$ & $14.5-16.5$ & $16.5-18.5$ & $18.5-20.5$ & \\
\hline $25 \%$ & 1 & 0 & 0 & 0 & 30 & 49 & 80 \\
\hline $50 \%$ & 1 & 0 & 2 & 0 & 37 & 121 & 162 \\
\hline $75 \%$ & 0 & 2 & 0 & 0 & 29 & 238 & 270 \\
\hline $100 \%$ & 2 & 2 & 0 & 0 & 36 & 261 & 302 \\
\hline $125 \%$ & 0 & 0 & 0 & 2 & 57 & 273 & 333 \\
\hline $150 \%$ & 2 & 0 & 0 & 0 & 76 & 302 & 381 \\
\hline $175 \%$ & 2 & 0 & 0 & 2 & 73 & 371 & 448 \\
\hline $200 \%$ & 0 & 2 & 0 & 2 & 99 & 377 & 480 \\
\hline
\end{tabular}

Perbandingan daya dukung friksi, ujung, dan ultimit pada fondasi tiang pancang, tiang bor, inner boring, dan data pengujian statik

Tabel 12. Perbandingan Daya Dukung pada DB-I

\begin{tabular}{cccc}
\hline Metode & Qs (Ton) & Qp (Ton) & Qu (Ton) \\
\hline Pancang Meyerhof & 402 & 1088 & 1490 \\
\hline Pancang Brown & 444 & 407 & 850 \\
\hline Pancang Briaud et al & 348 & 394 & 1475 \\
\hline Tiang Bor Meyerhof & 387 & 1089 & 656 \\
\hline Tiang Bor Reese and wright & 461 & 195 & 1047 \\
\hline Tiang Bor Luciano De Court & 483 & 564 & 1495 \\
\hline Inner Boring Nakabori & 516 & 980 & \\
\hline
\end{tabular}

Tabel 13. Perbandingan Daya Dukung pada DB-II

\begin{tabular}{cccc}
\hline Metode & Qs (Ton) & Qp (Ton) & Qu (Ton) \\
\hline Pancang Meyerhof & 495 & 1089 & 1584 \\
\hline Pancang Brown & 488 & 407 & 777 \\
\hline Pancang Briaud et al & 383 & 394 & 1534 \\
\hline Tiang Bor Meyerhof & 446 & 1089 & 734 \\
\hline Tiang Bor Reese and wright & 539 & 195 & 1553 \\
\hline Tiang Bor Luciano De Court & 560 & 993 & 1592 \\
\hline Inner Boring Nakabori & 613 & 980 & \\
\hline
\end{tabular}

Tabel 14. Perbandingan Daya Dukung pada DB-III

\begin{tabular}{cccc}
\hline Metode & Qs (Ton) & Qp (Ton) & Qu (Ton) \\
\hline Pancang Meyerhof & 503 & 1188 & 1690 \\
\hline Pancang Brown & 527 & 443 & 807 \\
\hline Pancang Briaud et al & 401 & 406 & 1673 \\
\hline Tiang Bor Meyerhof & 486 & 1188 & 799 \\
\hline Tiang Bor Reese and wright & 586 & 212 & 1280 \\
\hline Tiang Bor Luciano De Court & 639 & 640 & 1664 \\
\hline Inner Boring Nakabori & 595 & 1069 & \\
\hline
\end{tabular}




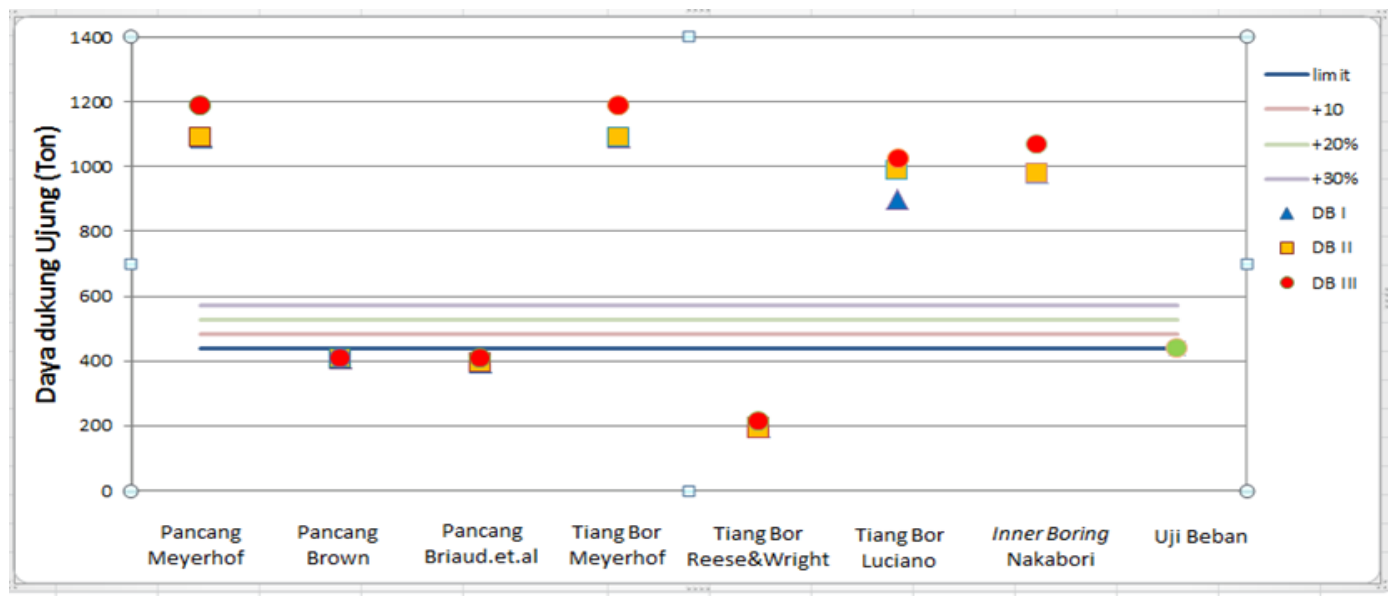

Gambar 2. Perbandingan Skin Friction DB-I, DB-II, DB-III

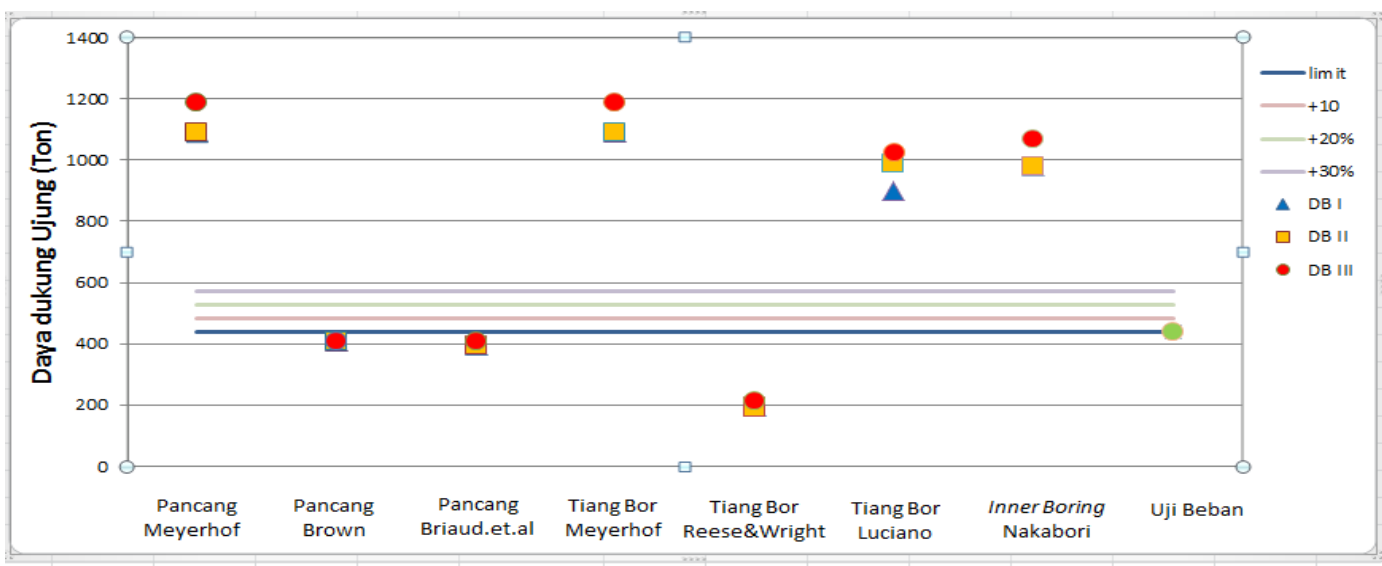

Gambar 3. Perbandingan End Bearing DB-I, DB-II, DB-III

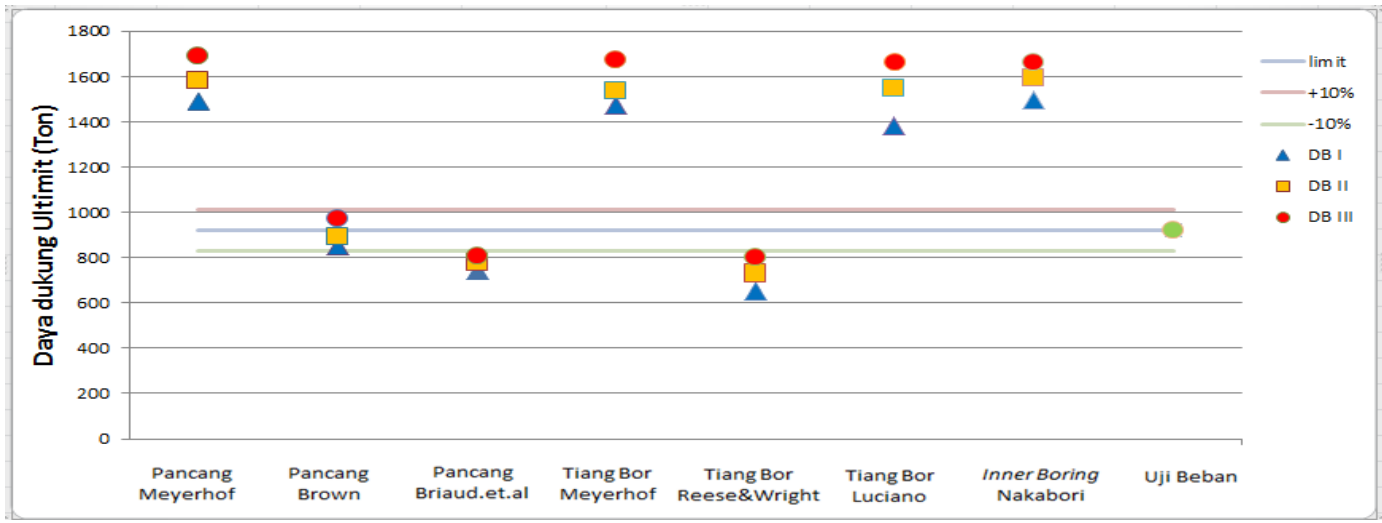

Gambar 4. Daya Dukung Ultimit DB-I, DB-II, DB-III 


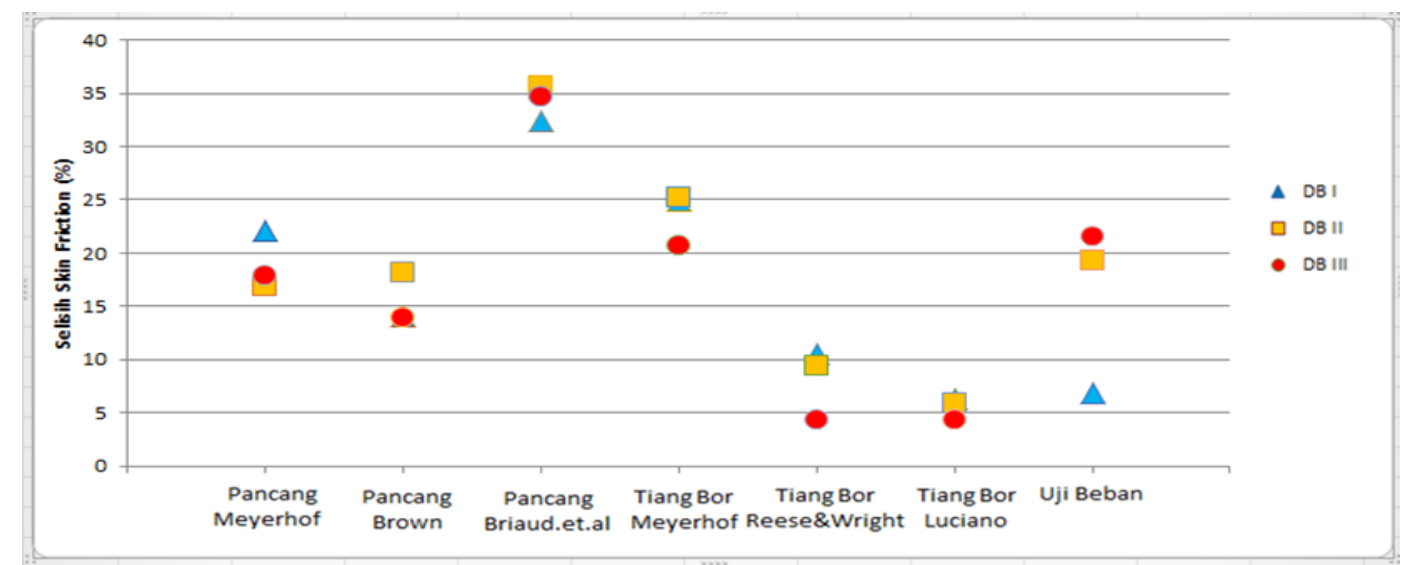

Gambar 5. Selisih Daya Dukung Ultimit DB-I, DB-II, DB-III

\section{KESIMPULAN}

Dari analisis perbandingan perhitungan kapasitas daya dukung fondasi maka dapat ditarik kesimpulan sebagai berikut:

1.Perhitungan daya dukung fondasi tiang pancang dengan metode Brown konsisten memberikan perkiraan kapasitas daya dukung friksi dan ujung yang paling mendekati kapasitas daya dukung friksi dari uji pembebanan statik (loading test).

2.Perhitungan daya dukung ujung tiang dari data uji pembebanan statik belum mencapai daya dukung ujung ulitimit karena tiang belum mengalami deformasi maksimum $(25.4 \mathrm{~mm})$ sedangkan tiang yang diujikan dalam uji pembebanan statik mengalami deformasi sebesar $18.14 \mathrm{~mm}$.

3.Perhitungan daya dukung fondasi Inner Boring dengan metode Nakabori memberikan perkiraan kapasitas daya dukung tiang baik daya dukung friksi maupun ujung yang lebih besar dari data beban aktual yang dapat dipikul oleh tiang yang didapat dari uji pembebanan statik (loading test).

\section{DAFTAR PUSTAKA}

Hardiyatmo, H. C. (2008). Teknik Fondasi 2. PT Gramedia Pustaka Utama, Jakarta

Kawanda, A. ,. (2015). "Bearing Capacity of Precast Concrete Spun Pile Installed with Inner-Bore Method".2

Lymon C.Reese, W. M.(2006). Analysis and desain of shallow and deep foundation. John Wiley \& sons, INC., USA

Rahardjo, Paulus, P. (2013). Manual Pondasi Tiang. Parahyangan Catholic University,Bandung 